\title{
Correction to: Insights into Ethiopian honey bee diversity based on wing geomorphometric and mitochondrial DNA analyses
}

\author{
Teweldemedhn Gebretinsae HaIlu ${ }^{1,2}$, Paul D’Alvise ${ }^{1}$, Adam Tofilski ${ }^{3}$, Stefan Fuchs ${ }^{4}$, \\ Juergen Greiling ${ }^{5}$, Peter Rosenkranz ${ }^{6}$, Martin HasselmanN ${ }^{1}$ \\ ${ }^{1}$ Faculty of Agricultural Sciences, Institute of Animal Science, Department of Livestock Population Genomics, Uni- \\ versity of Hohenheim, Garbenstraße 17, 70599, Stuttgart, Germany \\ ${ }^{2}$ Faculty of Agriculture, Department of Animal Sciences, Aksum University, P.O. Box 314, Shire, Ethiopia \\ ${ }^{3}$ Department of Zoology and Animal Welfare, University of Agriculture in Krakow, Kraków, Poland \\ ${ }^{4}$ Oberursel Bee Research Institute, Goethe University Frankfurt am Main, Karl-von-Frisch-Weg 2, 61440, Oberursel, \\ Germany \\ ${ }^{5}$ Ethiopian Apicultural Board, Legehar, Churchill Avenue, Tekilu Desta Bldg, P.O. Box 2307, Addis Ababa, Ethiopia \\ ${ }^{6}$ State Institute of Bee Research, University of Hohenheim, August-von-Hartmann-Str. 13, 70599, Stuttgart, Germany
}

\section{Correction to: Apidologie (2020) 51:1182-1198 https://doi.org/10.1007/s13592-020-00796-9}

The article Insights into Ethiopian honey bee diversity based on wing geomorphometric and mitochondrial DNA analyses, written by Hailu, T.G., D’Alvise, P., Tofilski, A. et al., was originally published Online First without Open Access. After publication in volume 51, issue 6, page 1182-1198, the author decided to opt for Open Choice and to make the article an Open Access publication. Therefore, the copyright of the article has been changed to (C) The Author(s) 2020 and the article is forthwith distributed under the terms of the Creative Commons Attribution 4.0 International License, which permits use, sharing, adaptation, distribution, and reproduction in any medium or format, as long as you give appropriate credit to the original author(s) and the source, provide a link to the Creative Commons licence, and indicate if changes were made. The images or other third party material in this article is included in the article's Creative Commons licence, unless indicated otherwise in a credit line to the material. If material is not included in the article's Creative Commons licence and your intended use is not permitted by statutory regulation or exceeds the permitted use, you will need to obtain permission directly from the copyright holder. Open Access funding enabled and organized by Projekt DEAL.

Publisher's note Springer Nature remains neutral with regard to jurisdictional claims in published maps and institutional affiliations. 